\title{
Analysis of phytoplankton of the Australian sector of the Southern Ocean: comparisons of microscopy and size frequency data with interpretations of pigment HPLC data using the 'CHEMTAX' matrix factorisation program
}

\author{
S. W. Wright ${ }^{1, *}$, D. P. Thomas ${ }^{2, * *}$, H. J. Marchant ${ }^{1}$, H. W. Higgins ${ }^{3}$, M. D. Mackey ${ }^{3, * * *}$, \\ D. J. Mackey ${ }^{3}$
}

\begin{abstract}
${ }^{1}$ Australian Antarctic Division, Channel Highway, Kingston, Tasmania 7050, Australia
${ }^{2}$ Plant Science Dept, University of Tasmania, Hobart, Tasmania 7005, Australia

${ }^{3}$ CSIRO Division of Oceanography, PO Box 1538, Hobart, Tasmania 7001, Australia
\end{abstract}

\begin{abstract}
A new matrix factorization program 'CHEMTAX' was used to interpret high-performance liquid chromatography (HPLC) pigment data from a transect between Prydz Bay, Antarctica, and Australia during March 1987. The program calculated the abundance of diatoms, dinoflagellates, haptophytes resembling Emiliania huxleyi, haptophytes resembling Phaeocystis antarctica, cyanobacteria, prasinophytes, chlorophytes and cryptophytes along the transect. The results were compared with those of microscopy and particle size analysis. The transect was dominated by small cells: particle size analysis showed that particles $<2 \mu \mathrm{m}$ represented 27 to $44 \%$ of the total by number while particles 2 to $20 \mu \mathrm{m}$ represented 55 to $68 \%$. Particles $>20 \mu \mathrm{m}$ never represented more than $3 \%$ by number but constituted 57 to $93 \%$ of the total volume. Microscopic analysis showed that small flagellates were the most abundant cells along the transect, with a 5 -fold increase in abundance at $47^{\circ} \mathrm{S}$. Numbers of diatoms (most $<20 \mu \mathrm{m}$ in size) increased markedly south of the Polar Front, correlating with the concentration of silica. Dinoflagellate numbers were relatively constant along the transect, although somewhat higher north of $50^{\circ} \mathrm{S}$. Those $<20 \mu \mathrm{m}$ in size were most numerous and accounted for most of the latitudinal variation. Interpretation of HPLC pigment data using the CHEMTAX program was consistent with microscopical analysis. The computed abundances of diatoms and dinoflagellates correlated more strongly with the numbers of small $(<20 \mu \mathrm{m})$ diatoms and dinoflagellates, respectively, than with large ones. Computed cyanobacterial abundances correlated well with microscopical observations except for small errors where cyanobacteria were absent, probably due to misallocation of zeaxanthin from chlorophytes and prasinophytes. The program was able to distinguish 2 populations of haptophytes along the transect, representing Phaeocystis antarctica and coccolithophorids, even though their pigment compositions were qualitatively (though not quantitatively) identical. It also indicated the separate distributions of chlorophytes and prasinoxanthin-containing prasinophytes, and showed the presence of cryptophytes where none were observed by microscopy.
\end{abstract}

KEY WORDS: Phytoplankton - Antarctica - Southern Ocean - Pigment HPLC - Microscopy - Size analysis - CHEMTAX

\section{INTRODUCTION}

Until relatively recently, the phytoplankton of the Southern Ocean was believed to be dominated by

\footnotetext{
•E-mail: simon_wri@antdiv.gov.au

Present addresses: "'Taverner's Products, PO Box 35, Moonah, Tasmania 7009, Australia; $\cdots$ University Chemical Laboratory, Lensfield Rd, Cambridge CB2 1EW, United Kingdom
}

large diatoms. These were believed to form the base of a simple food chain, the diatoms being grazed directly by krill which in turn fed fish, seabirds, seals and whales. This concept was based on the analysis of samples collected by plankton nets which did not retain cells less than $20 \mu \mathrm{m}$ diameter.

More recent investigations have shown that the phytoplankton of the Southern Ocean is in fact numerically dominated by nanoplankton (Hewes et al. 1985 
Marchant \& Murphy 1994), as are other parts of the world's oceans (Hasle 1969, von Bröckel 1981). As well as diatoms, the nanoplankton has been found to contain haptophytes, chlorophytes, prasinophytes, chrysophytes and dinoflagellates (both autotrophic and heterotrophic) (El-Sayed \& Fryxel 1993, Garrison \& Gowing 1993). Cyanobacteria are virtually absent south of the Polar Front (Marchant et al. 1987).

Many of the smaller (picoplanktonic and nanoplanktonic) cells are very difficult to study. Their small size and absence of clearly discernible features often preclude identification by light microscopy, even to the class level, and many are too fragile to be adequately preserved for electron microscopy. Some groups of phytoplankton have been investigated in the Southern Ocean, e.g. diatoms (Kopczynska et al. 1986), cyanobacteria (Marchant et al. 1987), coccolithophorids and Parmales (Marchant \& McEldowney 1986, Nishida 1986, Booth \& Marchant 1987). In general, these organisms have features that survive fixation for electron microscopy or, in the case of cyanobacteria, have distinctive autofluorescence. Other cells that are not adequately preserved have been overlooked, notably the many varieties of autotrophic flagellates. In any case, electron microscopy is impractical for analysing large numbers of samples since many hundreds of cells must be counted in each sample to give statisticallysound results. Flow cytometry, on the other hand, gives excellent counting statistics and has proved invaluable for enumeration of cyanobacteria (Li \& Wood 1988) and prochlorophytes (Chisholm et al. 1988, Li \& Wood 1988, Vaulot et al. 1990), but identification of less distinctive cells remains a problem.

Analysis of photosynthetic pigments (chlorophylls and carotenoids) can identify taxonomic groups when it is difficult or impractical to identify and count individual cells. Many of the classes represented in the picoplankton and nanoplankton have distinctive suites of marker chlorophylls and carotenoids that indicate their presence and abundance in a mixed population (Millie et al. 1993, Jeffrey \& Vesk in press). Moreover, techniques for their extraction and analysis by highperformance liquid chromatography (HPLC) are suitable for the analysis of the hundreds of samples required in ecological studies.

Practical HPLC techniques for the analysis of phytoplankton pigments have been available since the early 1980s (reviewed by Roy 1987, Millie et al. 1993, Jeffrey in press). A comprehensive monograph on HPLC techniques and pigment data has just been produced by SCOR-UNESCO (Jeffrey et al. in press).

Interpretation of pigment HPLC data is not straightforward. While some pigments are unambiguous markers for particular phytoplankton classes, many markers are present in several classes. Unambiguous markers include: peridinin, Dinophyceae; prasinoxanthin, some Prasinophyceae (many prasinophytes have pigment compositions resembling Chlorophyceae); alloxanthin, Cryptophyceae; and divinylchlorophyll $a_{1}$ Prochlorophyceae. Other markers that are not confined to 1 class include: fucoxanthin, Bacillariophyceae, Haptophyceae, Dinophyceae; chlorophyll $b$ (chl b). Chlorophyceae, Prasinophyceae; 19'-hexanoyloxyfucoxanthin, Haptophyceae, Chrysophyceae (reviewed by Jeffrey \& Vesk in press). Determining the contributions of phytoplankton classes to the concentrations of these pigments is complex. Furthermore, the pigment composition of many algal classes is poorly known. HPLC surveys of pigments have been performed for diatoms (Stauber \& Jeffrey 1988) and Haptophyceae (Jeffrey \& Wright 1994), for which a maximum of 51 species have been examined. The designated pigment composition for several classes has been based on less than 5 species (Jeffrey \& Vesk in press). Symbioses may further complicate the interpretation. For instance, some dinoflagellates have been found with pigments characteristic of endosymbiotic chrysophytes (Jeffrey et al. 1975), haptophytes (Bjørnland \& Liaaen-Jensen 1989) or green algae (Watanabe et al. 1987, 1990), and the ciliate Mesodinium rubrum has been found to contain alloxanthin from a cryptomonad endosymbiont (Hibberd 1977).

Most interpretations of pigment data have been limited to the use of unambiguous markers or 'best-guess' deductions from ambiguous markers. Gieskes et al. (1988) used multiple linear regression to correlate the abundance of various markers (e.g. fucoxanthin) with chlorophyll a (chl a), but did not attempt to identify the source(s) of the markers.

A new approach, using matrix calculations, was developed as a MATLAB ${ }^{6}$-based program, CHEMTAX. In the companion paper, Mackey et al. (1996) characterised and tested CHEMTAX using artificial data. This paper uses CHEMTAX to interpret HPLC data from the Southern Ocean in conjunction with microscopy and size-fractionated particle counts.

We report a study of the distribution and abundance of phytoplankton across the Southern Ocean between Antarctica and Australia, using and comparing several techniques. The transect ranged from Antarctic to subtropical waters and covered a wide range of phytoplankton communities, water temperatures and nutrient regimes. It offered a useful test of the CHEMTAX program, since the general characteristics of the phytoplankton were already known. Direct counts were available for cells identifiable by shipboard microscopy-diatoms, dinoflagellates (both size-fractionated) and cyanobacteria-plus a group of cells operationally classified as 'monads + flagellates' which were too small for shipboard identification. This last group is 
typically dominated by haptophytes, prasinophytes and chlorophytes in these waters, with the haptophytes being predominantly Phaeocystis antarctica to the south and coccolithophorids to the north of the Polar Front Thus, there was a strong basis for evaluating the results of the CHEMTAX interpretation and to compare them with the results of more traditional methods.

\section{MATERIALS AND METHODS}

Sample collection. Samples were collected from the surface along a transect from Prydz Bay, Antarctica, to Hobart, Tasmania, between 23 March and 1 April 1987 from MV 'Nella Dan'. The cruise track is shown in Fig. 1, which shows the groupings of stations determined by principal components analysis of the results (see below). The temperature of each sample was measured immediately after bringing it on deck. Aliquots were frozen for analysis of nitrate, phosphate and silicate. Salinity samples were analysed on return to Australia using a Yeo-Kal inductive salinometer.

Microscopy. Cyanobacteria were counted by filtering $100 \mathrm{ml}$ of seawater through a $0.2 \mu \mathrm{m}$ pore size, $25 \mathrm{~mm}$ diameter Nuclepore filter. The filters were examined immediately by epifluorescence microscopy using a Zeiss WL microscope fitted with a $\mathrm{HBO} 50$ mercury vapour lamp, a BP 450-490 exciter filter, FT 510 dichroic beam splitter and LP 520 barrier filter. The microscope was shock mounted to minimize vibrations from the ship's engines (Marchant 1985). Yellow autofluorescent picoplankton in 40 fields of

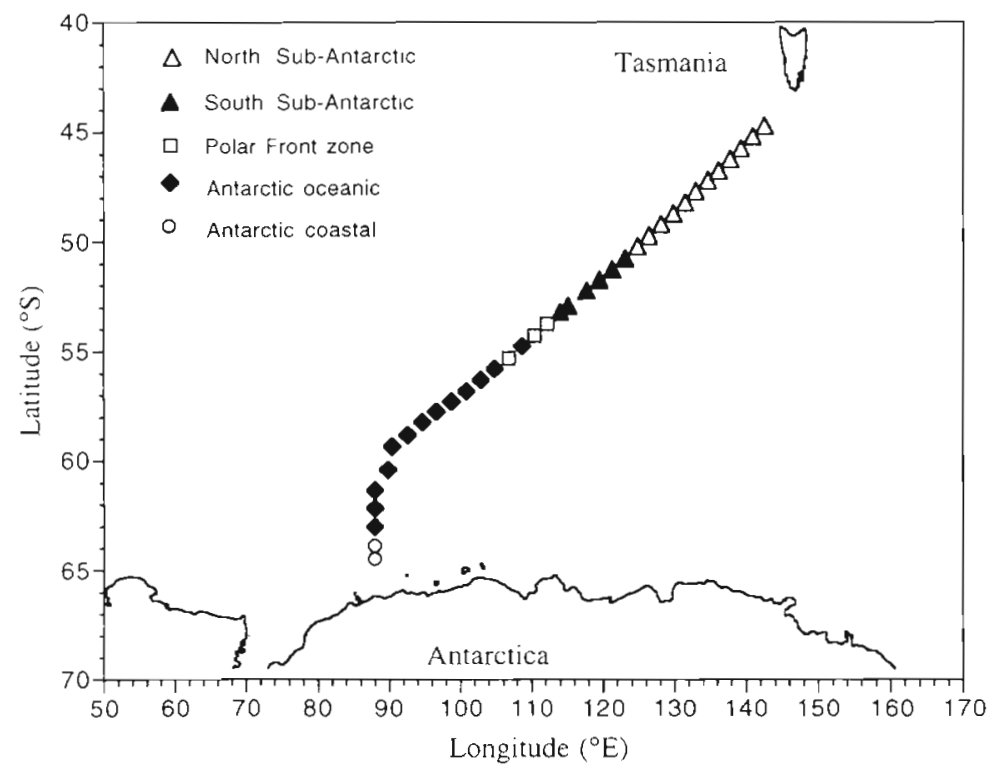

Fig. 1 Sampling locations between Prydz Bay, Antarctica, and Hobart, Australia. Stations were categorized according to associations determined by principal components analysis, as indicated in key view for each sample were counted using a $40 \times$ oilimmersion objective.

The concentration of eukaryotic protists was also determined by shipboard phase-contrast microscopy. Up to 11 of seawater was gently filtered through a $0.8 \mathrm{~mm}$ pore-sized, $47 \mathrm{~mm}$ diameter Nuclepore filter until it nearly clogged, leaving 2 to $5 \mathrm{ml}$ of water with concentrated organisms above the filter The cells were gently resuspended with a pasteur pipette and, after measuring the volume, a drop of the concentrate was placed on a microscope slide, covered, and the cells were counted in 5 random transects across the coverslip with $40 \times$ oil-immersion objective, using the following categories: diatoms $(>20 \mu \mathrm{m})$, diatoms $(<20 \mu \mathrm{m})$, dinoflagellates $(>20 \mu \mathrm{m})$, dinoflagellates $(<20 \mu \mathrm{m})$, and monads + flagellates.

For size fractionation and microscopy, 2 l of seawater was fixed with a mixture of Lugol's iodine and glutaraldehyde. On return to Australia, the particle size spectrum in a $100 \mathrm{ml}$ aliquot was determined using a HIAC RoyCo PC-320 optical particle-size analyser. Phytoplankton in the remainder of the sample were settled for enumeration and identification by light microscopy.

Pigment analysis. Phytoplankton from 3 to $5 \mathrm{l}$ of seawater were filtered onto Whatman GF/F glass-fibre filters (47 mm diam.) using a vacuum of less than $0.5 \mathrm{~atm}$. All pigment samples were stored in liquid nitrogen for return to Australia, where the chlorophyll and carotenoid pigments were extracted and analysed using the HPLC technique of Wright \& Shearer (1984). [This technique has since been superseded (Wright et al. 1991, Wright \& Jeffrey in press) and is no longer recommended.] Equipment comprised Waters 6000A and M45 pumps, U6K injector, 440 absorbance detector (operated at 405 and $436 \mathrm{~nm}$ ) and an Hitachi 1100 fluorescence detector (operated in zero-order mode and equipped with Turner filters: 370 to $500 \mathrm{~nm}$ bandpass, excitation; >604 nm longpass, emission) all connected via a Waters System Interface Module to a computer controller/integrator running Waters Maxima software Pigments were initially identified only by retention time, as the concentrations were too low for UV-visible spectra to be obtained; however, after all samples were analysed. they were pooled, concentrated and confirmatory spectra were collected using a Hewlett-Packard 8450A spectrophotometer.

Data analysis. Combined results for all stations (temperature, salinity, nutrients, pigments and cell counts) were analysed by principal components analysis. Five groups of stations were identified, referred to as 
Table 1. Pigment ratios for various taxonomic groups after conclusion of the CHEMTAX program. Pigment abbreviations: PER, peridinin; BUT, 19'-butanoyloxyfucoxanthin; FUCO, fucoxanthin; HEX, 19'-hexanoyloxyfucoxanthin; NEO, neoxanthin; PRAS, prasinoxanthin; VIOL, violaxanthin; ALLO, alloxanthin; LUT, lutein; ZEA, zeaxanthin; CHL b, chlorophyll b; CHL a, chlorophyll a

\begin{tabular}{lccccccccccccc}
\hline & PER & BUT & FUCO & HEX & NEO & PRAS & VIOL & ALLO & LUT & ZEA & CHL $b$ CHL $a$ TOTAL \\
\hline Prasinophytes & 0 & 0 & 0 & 0 & 0.064 & 0.068 & 0.042 & 0 & 0.004 & 0 & 0.400 & 0.423 & 1.000 \\
Dinoflagellates & 0.515 & 0 & 0 & 0 & 0 & 0 & 0 & 0 & 0 & 0 & 0 & 0.485 & 1.000 \\
Cryptophytes & 0 & 0 & 0 & 0 & 0 & 0 & 0 & 0.186 & 0 & 0 & 0 & 0.814 & 1.000 \\
Haptophytes-N & 0 & 0.012 & 0.047 & 0.471 & 0 & 0 & 0 & 0 & 0 & 0 & 0 & 0.471 & 1.000 \\
Haptophytes-S & 0 & 0.023 & 0.207 & 0.259 & 0 & 0 & 0 & 0 & 0 & 0 & 0 & 0.512 & 1.000 \\
Chlorophytes & 0 & 0 & 0 & 0 & 0.040 & 0 & 0.034 & 0 & 0.127 & 0.006 & 0.165 & 0.628 & 1.000 \\
Cyanobacteria & 0 & 0 & 0 & 0 & 0 & 0 & 0 & 0 & 0 & 0.258 & 0 & 0.742 & 1.000 \\
Diatoms & 0 & 0 & 0.375 & 0 & 0 & 0 & 0 & 0 & 0 & 0 & 0 & 0.625 & 1.000 \\
\end{tabular}

Antarctic coastal, Antarctic oceanic, Polar Front zone, South Sub-Antarctic, and North Sub-Antarctic. These groups of stations are shown in Fig. 1.

Pigment HPLC data was interpreted using CHEMTAX, a matrix factorization program running under MATLAB ${ }^{(}$. The basis of calculations and procedures used are described in the companion paper (Mackey et al. 1996). The taxonomic groups and the pigments used in the analysis are shown in Table 1. Initially, the samples were all analysed together, rather than being separated into different zones, since we wished to test the ability of the program to distinguish major changes along the transect, in particular, the change of dominant haptophytes from Phaeocystis antarctica in polar waters to coccolithophorids in temperate waters. Subsequently, the data set was split at $55^{\circ} \mathrm{S}$ (corresponding to the transition from Antarctic to sub-Antarctic waters). It was considered that there were too few samples in the other zones to justify further division of the data.

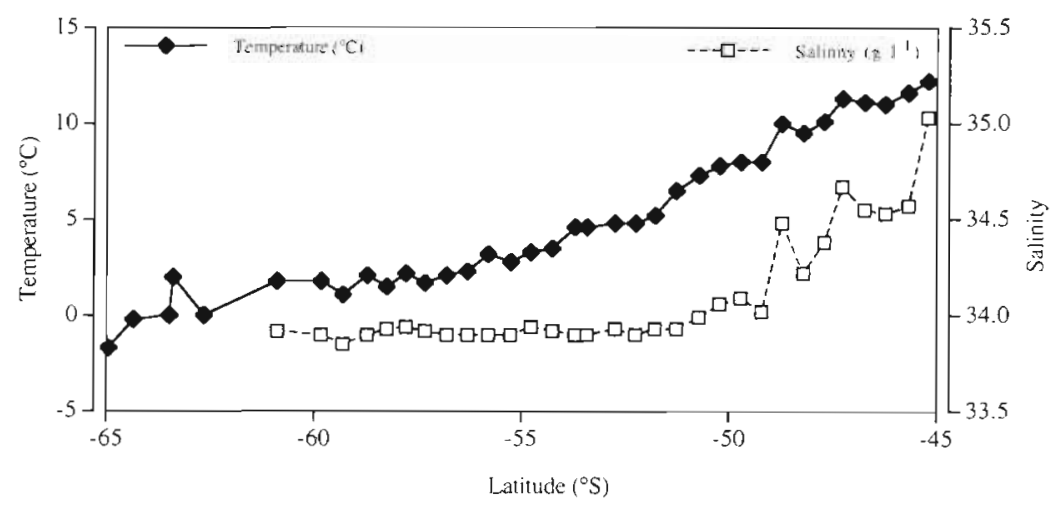

Fig. 2. Temperature and salinity of surface water across the transect in relation to latitude

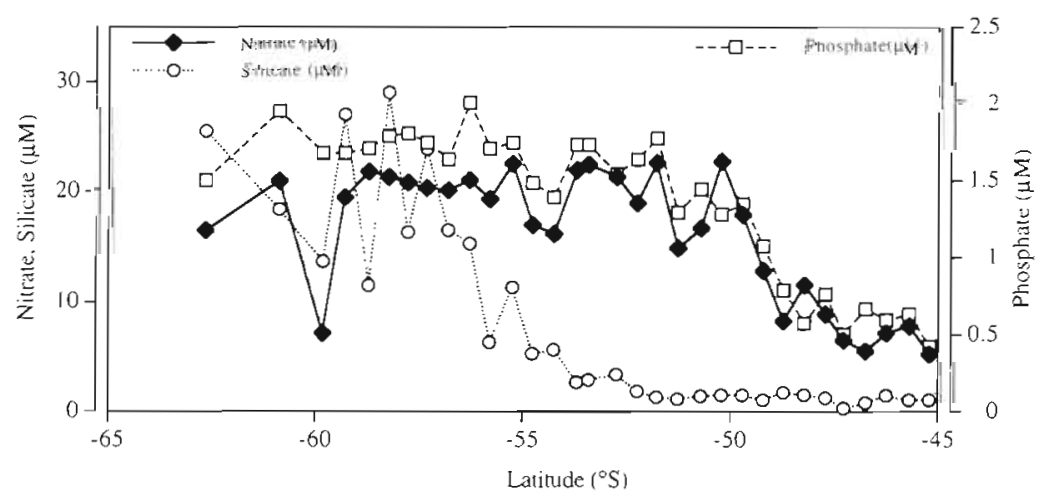

Fig. 3. Concentrations of nitrate, phosphate and silicate across the transect in relation to latitude

\section{RESULTS AND DISCUSSION}

\section{Physical and chemical data}

The latitudinal variation of temperature and salinity of surface samples along the transect is shown in Fig. 2. (Salinity samples south of $61^{\circ} \mathrm{S}$ were lost after they froze.) The concentrations of nitrate, phosphate and silicate are shown in Fig. 3

The transect crossed the Polar Front, the Sub-Antarctic Front and probably reached subtropical water at the last station, although the exact positions of these features are not obvious from the surface temperature data. These oceanographic features are characterized by subsurface phenomena (e.g. where the temperature minimum characteristic of Antarctic water dips below $200 \mathrm{~m}$; Deacon 1982)) which may not always show a strong signature at the surface (e.g. Edwards \& Emery 1982, Lutjeharms 1985) and may be displaced by 1 to $2^{\circ}$ latitude from any surface manifestation (Deacon 1982). In addition, the situation may be complicated by the presence of eddy fields along the interface between the 2 water 
masses (Gordon et al. 1977) We located the Polar Front at about $56^{\circ} \mathrm{S}$ and the SubAntarctic Front at about $49^{\circ} \mathrm{S}$, based on a combination of the temperature, salinity and nutrient data. Of these data, the silicate concentration (Fig. 3) shows the most dramatic decline across the transect: from between 11 and $29 \mu \mathrm{M}$ south of the Polar Front to less than $3 \mu \mathrm{M}$ north of the SubAntarctic Front. Nitrate and phosphate concentrations also declined dramatically north of $50^{\circ} \mathrm{S}$. Overall, the nutrient concentrations closely followed those mapped by Wyrtki et al. (1971). Between $50^{\circ}$ and $45^{\circ} \mathrm{S}$, regions of warmer, salty water with low nitrate concentration interleaved with cooler, less salty water richer in nitrate. Comparison with the data of Nakai et al. (1986) suggests that the warmer water originated north of the Subtropical convergence and that the interleaving is probably due to an eddy field associated with that feature. A similar situation occurred at the Polar Front, where the cruise track left Antarctic Oceanic waters, entered the Polar Front zone, then re-encountered Antarctic Oceanic water before re-entering the Polar Front zone. This is clearly seen in the temperature, nitrate and silicate data (Figs. 2 \& 3 ).
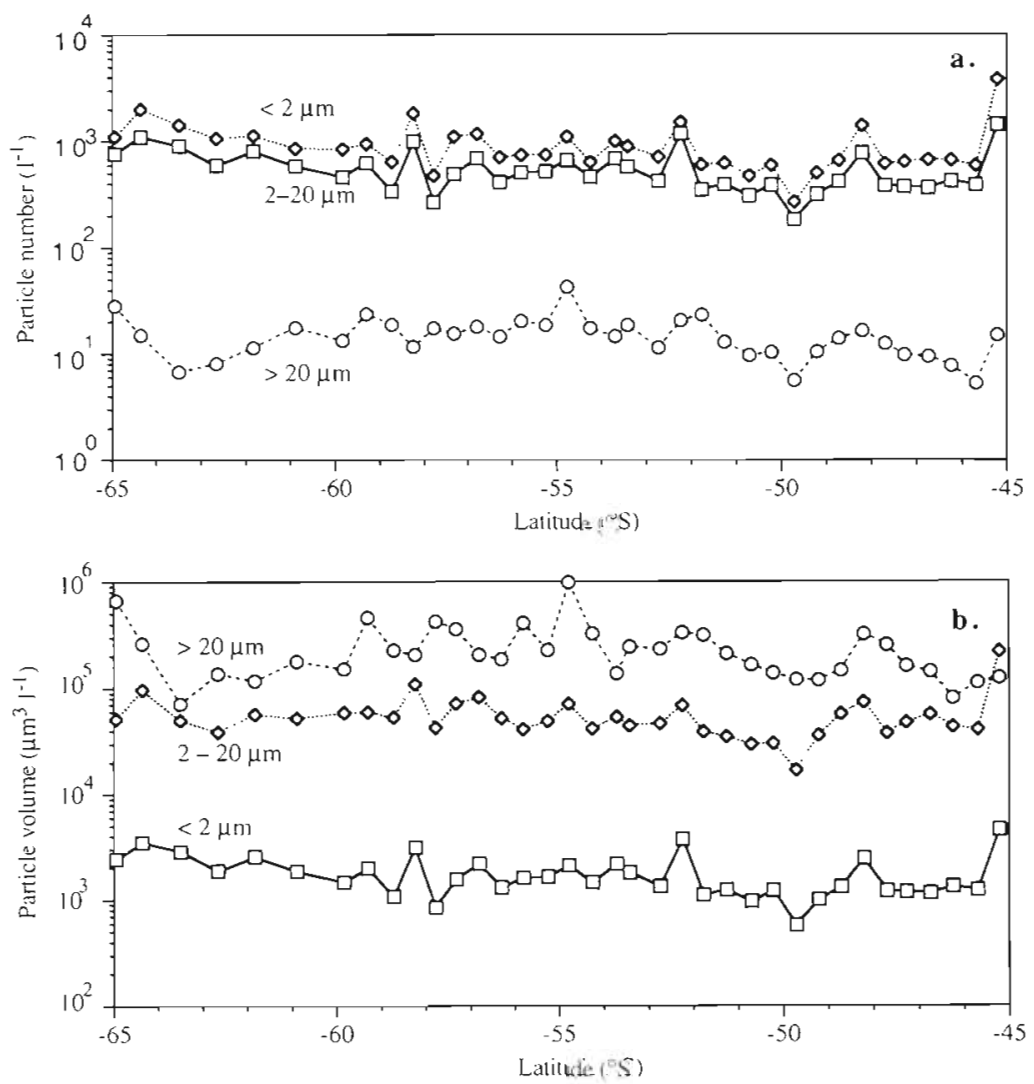

Fig. 4. Particle numbers and volumes across the transect as determined by laser particle counting: (a) Particle numbers per litre; (b) cell volumes $\left(\mu \mathrm{m}^{3} \mathrm{l}^{-1}\right)$. Particles were classified by size into 3 categories: $<2 \mu \mathrm{m}, 2$ to $20 \mu \mathrm{m}$ and $>20 \mu \mathrm{m}$

\section{Particle counter data}

Fig. $4 \mathrm{a}$, b shows the particle numbers and volumes across the transect (these include living cells as well as detritus). Particle numbers were relatively constant across the transect, with the averages in each area varying only between 1.22 and $1.81 \times 10^{6}$ particles $1^{-1}$ Particle volumes were more variable, with area aver-

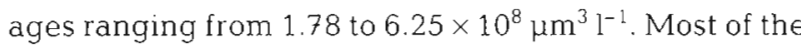
variation was due to particles greater than $20 \mu \mathrm{m}$. Small particles predominated numerically: those in the nanoplankton size range ( 2 to $20 \mu \mathrm{m}$ ) consistently represented 55 to $68 \%$ of the total number in individual samples, while particles $<2 \mu \mathrm{m}$ represented 27 to $44 \%$. The HIAC particle counter does not respond well to particles smaller than $2 \mu \mathrm{m}$ (Harris et al. 1987) so numbers in this size range are probably underestimated. However, the numerical importance of nano- and picoplankton-sized particles is demonstrated, supporting earlier observations of the importance of small phytoplankton [e.g. von Bröckel (1981) found $70 \%$ of phytoplankton carbon to be in cells $<20 \mu$ m diameter between Bellinghausen Sea and South Georgia].
Particles larger than $20 \mu \mathrm{m}$ never represented more than $3 \%$ of particles by number, but constituted 57 to $93 \%$ of the total particle volume, and accounted for most of the latitudinal variation in total volume. The greatest abundance of these microplankton-sized particles occurred in the Polar Front zone (corresponding to a drop in the concentrations of nitrate and phosphate) and in the Antarctic coast region.

\section{Microscopic data}

\section{Diatoms}

The distribution of nanoplanktonic ( 2 to $20 \mu \mathrm{m}$ ) and microplanktonic $(>20 \mu \mathrm{m})$ diatoms is shown in Fig. 5a, b. These represent the gross counts obtained for group counts. With the exception of one sample, nanoplanktonic diatoms always outnumbered microplanktonic ones. The numbers of both increased markedly south of the Polar Front. Smaller cells were most numerous near the Antarctic coast, where the numbers of microplanktonic diatoms declined. 

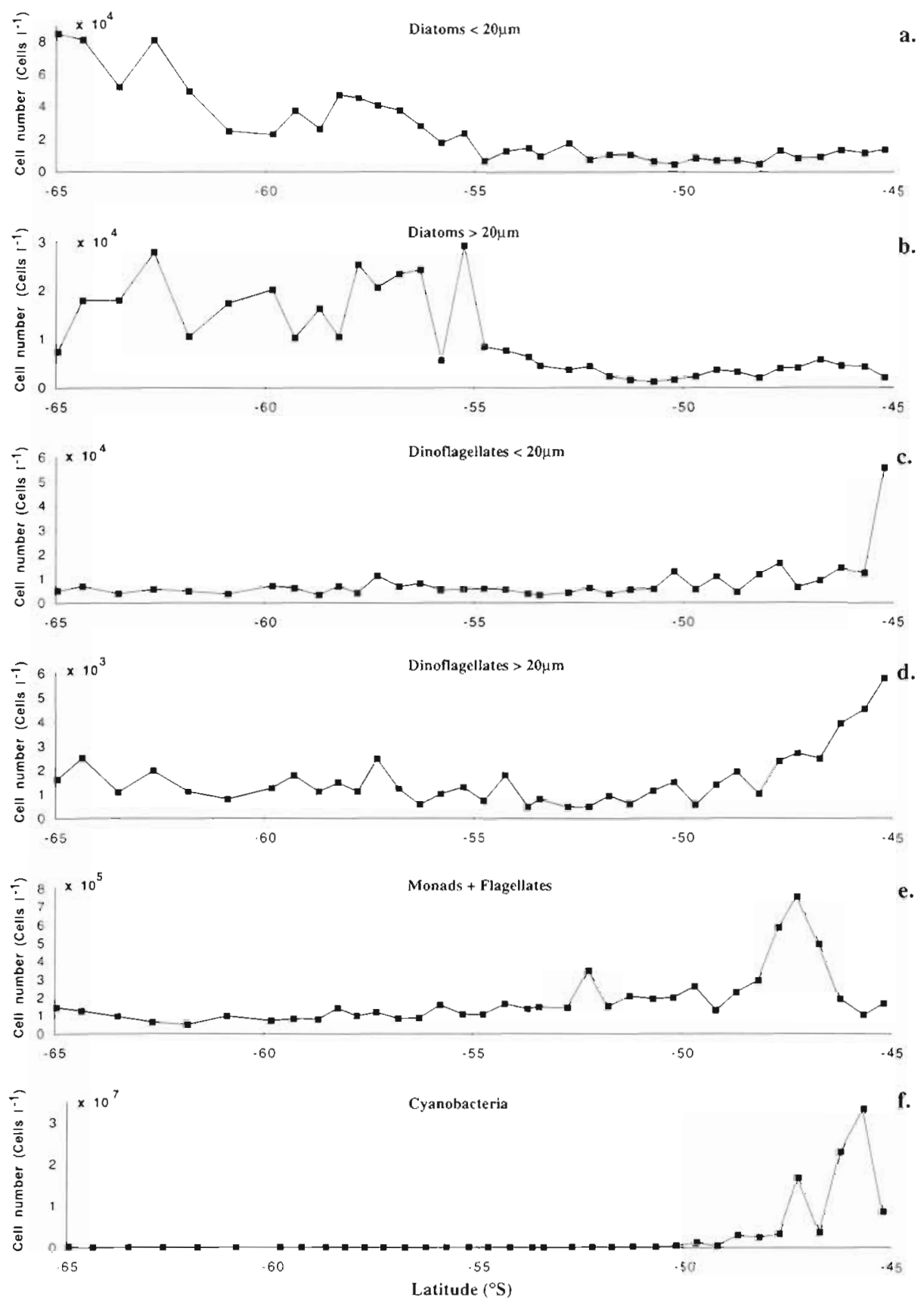

Fig. 5. Cell numbers $\left(1^{-1}\right)$ of (a) diatoms $(<20 \mu \mathrm{m})_{i}$ (b) diatoms $(>20 \mu \mathrm{m})_{i} \quad$ (c) dinoflagellates $(<20 \mu \mathrm{m}) ; \quad$ (d) dinoflagellates $(>20 \mu \mathrm{m})_{i} \quad$ (e) flagellates; (f) cyanobacteria; as determined by $(a-e)$ shipboard phase-contrast microscopy and (f) epifluorescence microscopy

Distributions of the most common species of diatom are shown in Fig. 6, in order of their abundance. The most numerous species were Fragilariopsis cylindrus, F. pseudonana, F. kerguelensis, Proboscia alata and F. curta. (The Fragilariopsis species were previously classified as Nitzschia, and $P$. alata was Rhizosolenia alata; Hasle \& Syvertsen 1996). Two species, F pseudonana and $F$. curta, were broadly distributed through Antarctic waters, whereas $F$, cylindrus and $P$. alata were restricted to southern Antarctic waters, and $F$. kerguelensis to northern Antarctic.

\section{Dinoflagellates}

Amongst the dinoflagellates, the nanoplanktonic forms also greatly outnumbered the microplankton (Fig. 5c, d). Numbers of nanoplanktonic dinoflagellate were relatively constant south of the Polar Front, with a gradual increase to the north before trebling in the northernmost sample. Microplanktonic dinoflagellates were less than a third as numerous as nanoplanktonic forms. They declined north of the Sub-Antarctic Front followed by a steady rise to $5 \times 10^{3}$ cells l $^{-1}$ 

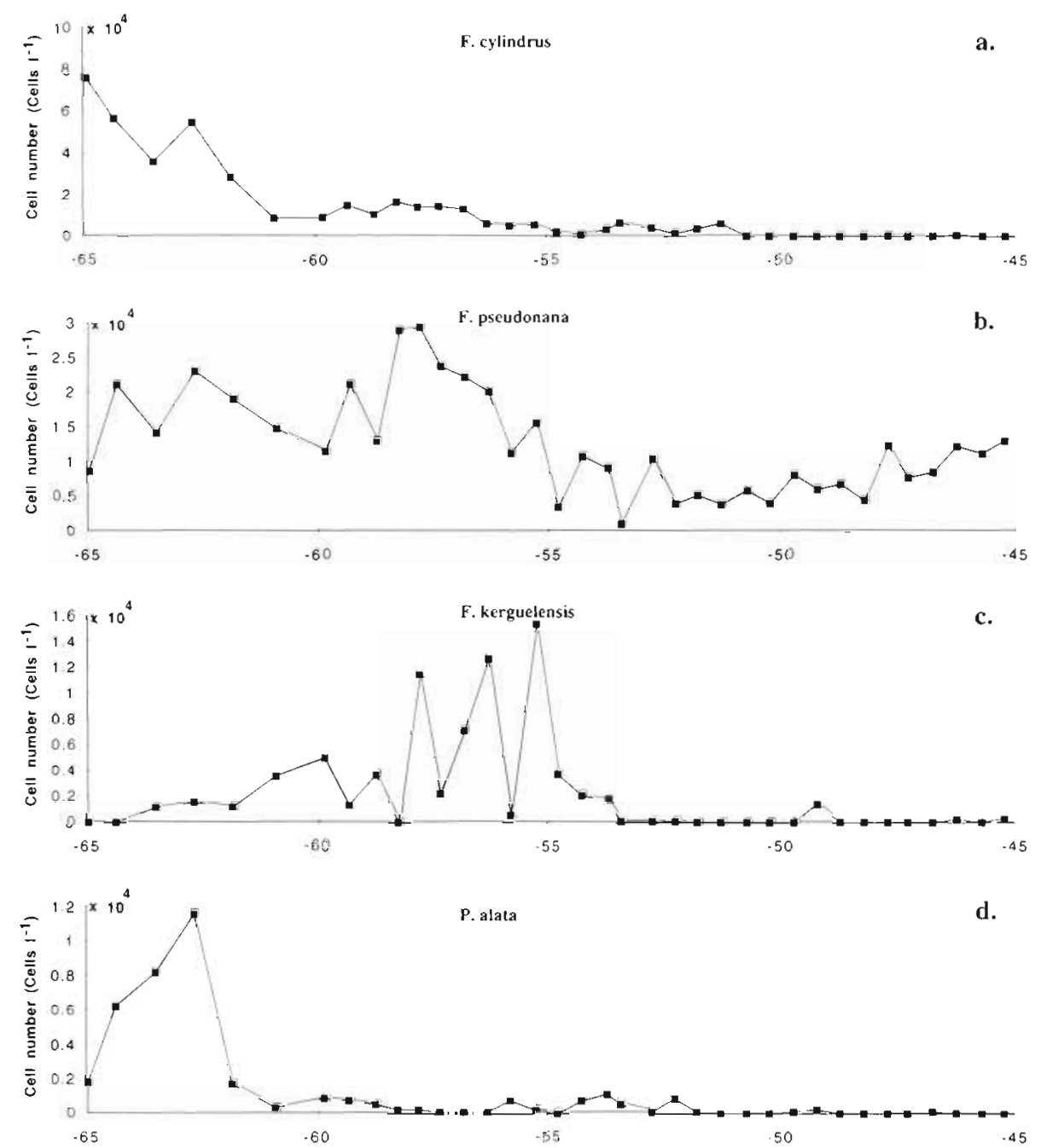

Fig 6. Cell numbers of the most numerous diatom species as determined by microsopy of settled, fixed cells: (a) Fragilariopsis cylindrus; (b) F. pseudonana; (c) F. kerguelensis; (d) Proboscia alata; (e) F. curta

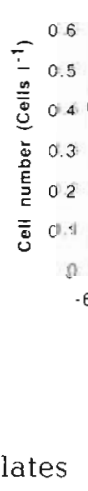

Fig. 5e shows the numbers of cells grouped as 'monads + flagellates': those too small to be differentiated by light microscopy, including both autotrophic and heterotrophic organisms. These cells were quite abundant, with $1.6 \times 10^{5}$ cells $1^{-1}$ near the Antarctic coast, dropping to $0.6 \times 10^{5}$ cells $1^{-1}$ at $62^{\circ} \mathrm{S}$ then increasing steadily northward. A dramatic increase $\left(7.7 \times 10^{5}\right.$ cells $\left.1^{-1}\right)$ was found at $47^{\circ} \mathrm{S}$, corresponding with one of the warm, saline regions crossed in the transect.
F. curta

e.

\section{Monads + flagellates}

Cyanobacteria
Cyanobacterial counts by autofluorescence (Fig. 5f) showed that they were virtually non-existent south of $50^{\circ} \mathrm{S}$ : occasionally 1 or 2 cells were seen per 40 microscope fields. North of this, however, a dramatic increase in cell numbers occurred, with concentrations of $3.4 \times 10^{7}$ cells $\mathrm{l}^{-1}$ being found at $46^{\circ} \mathrm{S}$, slightly north of the peak of monads + flagellates. 
Fig. 7. Concentrations of major pigments $\left(\mu g \mathrm{l}^{-1}\right)$ across the transect: (a) chl a; (b) fucoxanthin; (c) 19'-hexanoyloxyfucoxanthin; (d) 19'-butanoyloxyfucoxanthin; (e) peridinin; (f) chl $b$; (g) prasinoxanthin; (h) lutein; (i) zeaxanthin; (j) alloxanthin
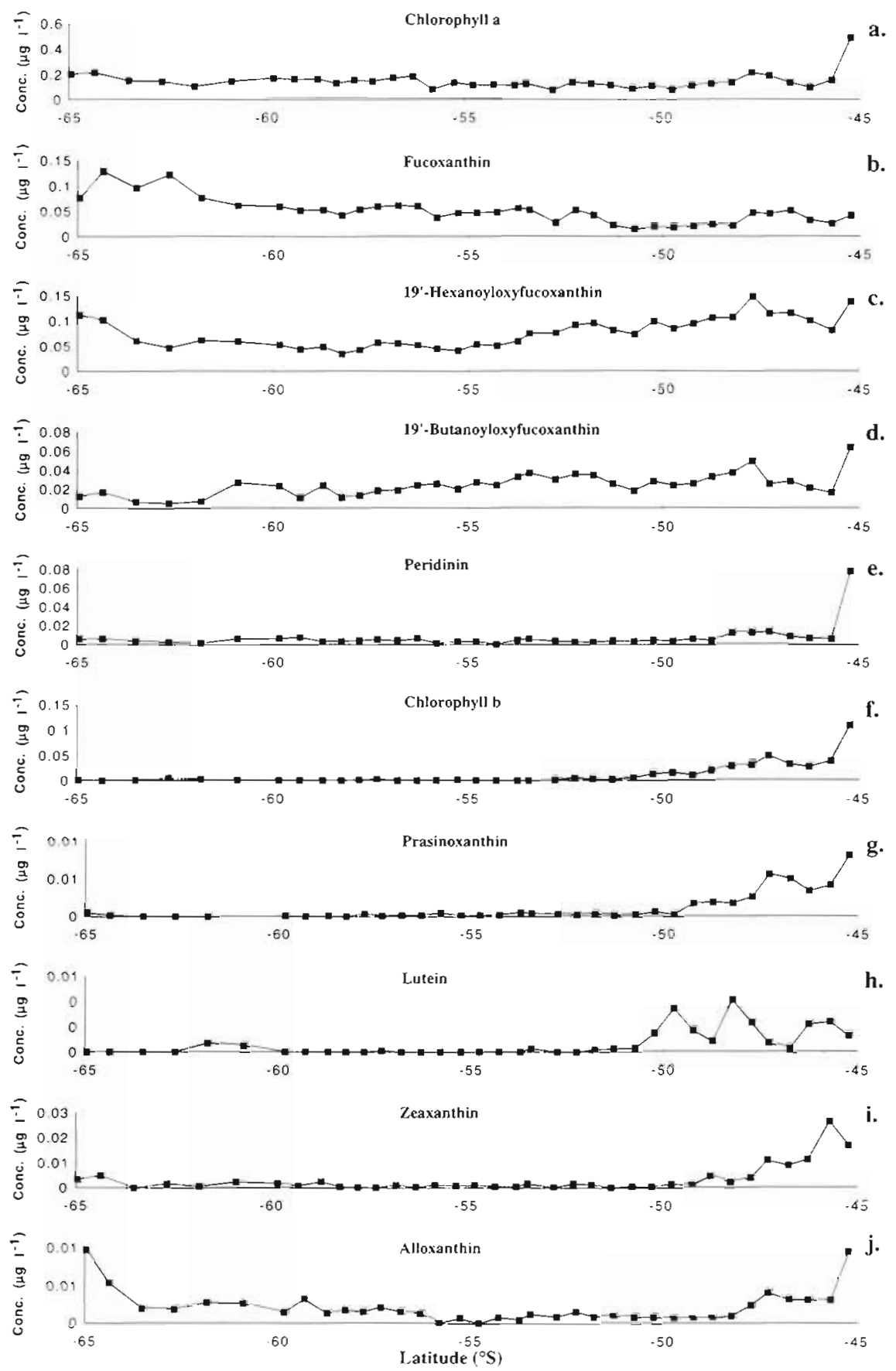

\section{Pigment data}

Concentrations of chl a were relatively low across the transect (Fig. 7a), ranging between 0.08 and 0.25 $\mu \mathrm{g} \mathrm{l}^{-1}$ in all but the northernmost sample $\left(0.49 \mu \mathrm{g}^{-1}\right)$. These values are consistent with sparse autumn populations after the summer maximum.

The concentration of fucoxanthin, the major carotenoid of diatoms, was greatest in southern samples
(Fig. 7b) corresponding to the abundance of diatoms. Fucoxanthin is not an unambiguous marker for diatoms since it is also found in haptophytes and chrysophytes, but in these samples there was a reasonably strong correlation $\left(\mathrm{r}^{2}=0.84\right)$ between numbers of diatoms (small and large) and fucoxanthin concentration (using multiple linear regression).

The concentrations of 19'-hexanoyloxyfucoxanthin (19'-hex, Fig. 7c) were similar to those of fucoxanthin 
south of the Sub-Antarctic Front but to the north it was approximately 3 times as abundant as fucoxanthin. There was a peak of abundance at $47^{\circ} \mathrm{S}$ corresponding to the peak abundance of flagellates (Fig. 5e).

The distribution pattern of 19'-butanoyloxyfucoxanthin (19'-but, Fig. 7d), which is found in some chrysophytes and haptophytes (Wright \& Jeffrey 1987), resembled that of $19^{\prime}$-hex north of the Polar Front, although the concentration was much lower. There was a similar peak at $47^{\circ} \mathrm{S}$ corresponding to the flagellate peak and a rise at $45^{\circ} \mathrm{S}$. South of the Polar Front, there was not the close similarity to the $19^{\prime}$-hex distribution; the large peak seen near the Antarctic coast in 19' -hex was not seen in 19'-but. Clearly, there were different sources for the 2 pigments in this region.

Peridinin, an unequivocal marker for dinoflagellates, was generally in low concentrations across the transect except for a small peak at $47^{\circ} \mathrm{S}$, and a very large peak at $45^{\circ} \mathrm{S}$ (Fig. 7e). The concentration of peridinin correlated well with the abundance of small and large dinoflagellates $\left(\mathrm{r}^{2}=0.95\right)$. The peak of peridinin concentration at $47^{\circ} \mathrm{S}$ was not matched by any rise in the counts of dinoflagellates observed by light microscopy, but did correspond to the 'monads+flagellates' peak, suggesting that the flagellates in this region, at least, must have included dinoflagellates too small (or too fragile) to be recognized by light microscopy.

The distribution of pigments associated with green algae (Chlorophyceae and Prasinophyceae) are shown in Figs $7 \mathrm{f}-\mathrm{h}$. Chl $b$ (Fig. 7f) is found in both classes. There was very little chl $b$ south of $51^{\circ} \mathrm{S}$ apart from a small peak in the southern Antarctic Oceanic samples. The peak at $47^{\circ} \mathrm{S}$ corresponded to the flagellate peak and there was a large peak at $45^{\circ} \mathrm{S}$. The distribution of prasinoxanthin, which is an unequivocal marker for some prasinophytes, was strongly correlated $\left(r^{2}=0.90\right)$ with that of chl $b$ north of $51^{\circ} \mathrm{S}$ (Fig. $7 \mathrm{~g}$ ), suggesting that most of the chl $b$ in this region (including the flagellate peak) arises from prasinophytes. There was no prasinoxanthin peak at $63^{\circ} \mathrm{S}$, showing that prasinoxanthin-containing prasinophytes were not represented there (this does not exclude the presence of other prasinophytes which lack prasinoxanthin). The distribution of lutein, the major carotenoid of the Chlorophyceae, is shown in Fig. 7h. Concentrations were very low across the transect. In the Antarctic Oceanic area there was a peak of $8 \times 10^{-4} \mathrm{Mg} \mathrm{l}^{-1}$, corresponding to the peak observed for chl $b$ in this region; however, in the northern Sub-Antarctic samples, the concentrations did not follow those of chlorophyll $b$ at all, suggesting a non-chlorophycean origin for most of the chlorophyll $b$ in this region.
The distribution of zeaxanthin is shown in Fig. 7i. It is the major carotenoid of marine cyanobacteria (notably Synechococcus sp.), but it is also present in Prochlorophyceae, Chlorophyceae and Prasinophyceae and must therefore be used cautiously as a marker for cyanobacteria. In this transect, a steady increase was observed north of $50^{\circ} \mathrm{S}$ which peaked at $46^{\circ} \mathrm{S}$. This distribution was strongly correlated $\left(\mathrm{r}^{2}=\right.$ 0.81 ) with the distribution of cyanobacteria (Fig. 5f). Some zeaxanthin was observed south of the Polar Front, where cyanobacteria were virtually absent, implying that green algae may have been the source in this region.

The distribution of the unequivocal cryptophyte marker, alloxanthin, is shown in Fig. 7j. This was highest near the Antarctic coast, dropped sharply in the Antarctic oceanic zone and fell below detectability in the Polar Front zone before rising sharply to the north. No free-living cryptophytes were recognised by microscopy; however, cryptophytes may have been present as endosymbionts in the ciliate Mesodinium rubrum (Hibberd 1977). This species has been observed in other Antarctic locations: blooming under sea-ice near Syowa station (Satoh \& Watanabe 1991), in sea-ice brine near McMurdo (Stoecker et al. 1993) and in many saline lakes of the Vestfold Hills (Perris et al. 1995). Ciliates were counted along with the phytoplankton in this study, but their numbers were so small that good statistics could not be obtained on the small sample volumes appropriate for counting phytoplankton (the maximum concentration of $1.5 \times 10^{3}$ ciliates $l^{-1}$ represented only 13 cells observed and these would have included heterotrophic ciliates as well as $M$. rubrum). The abundance of alloxanthin correlated poorly with total ciliates $\left(r^{2}=0.18\right)$, but because of the poor counting statistics and the presence of heterotrophic ciliates, this source cannot be excluded.

\section{CHEMTAX interpretation of pigment data}

The pigment data-set was analysed by CHEMTAX in 2 ways. First, the entire data-set was computed to test the ability of the program to differentiate the northern and southern populations, in particular, the change of dominant haptophytes from coccolithophorids in the north to Phaeocystis in the south. Secondly, the data-set was split at $55^{\circ} \mathrm{S}$, corresponding to the Polar Front that separates Antarctic from subAntarctic waters. This strategy was recommended by Mackey et al. (1996) to reduce the variation of pigment ratios (which the model assumes to be constant) due to changes in species composition across a sample set. In fact, the former strategy was found to be more successful in this case, as shown below. 

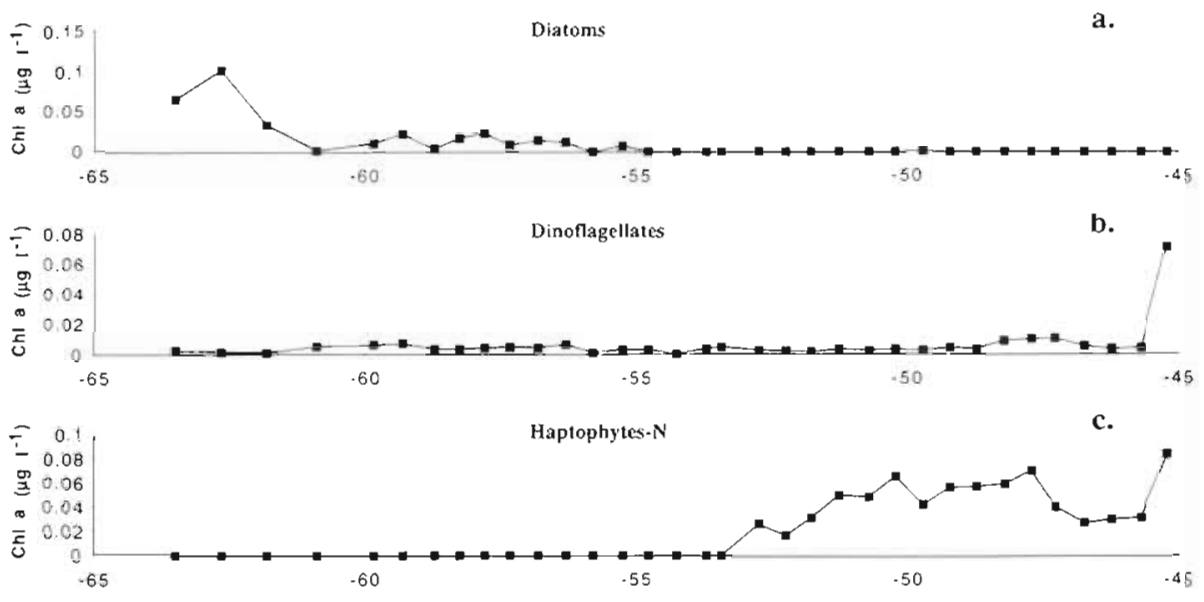

d.
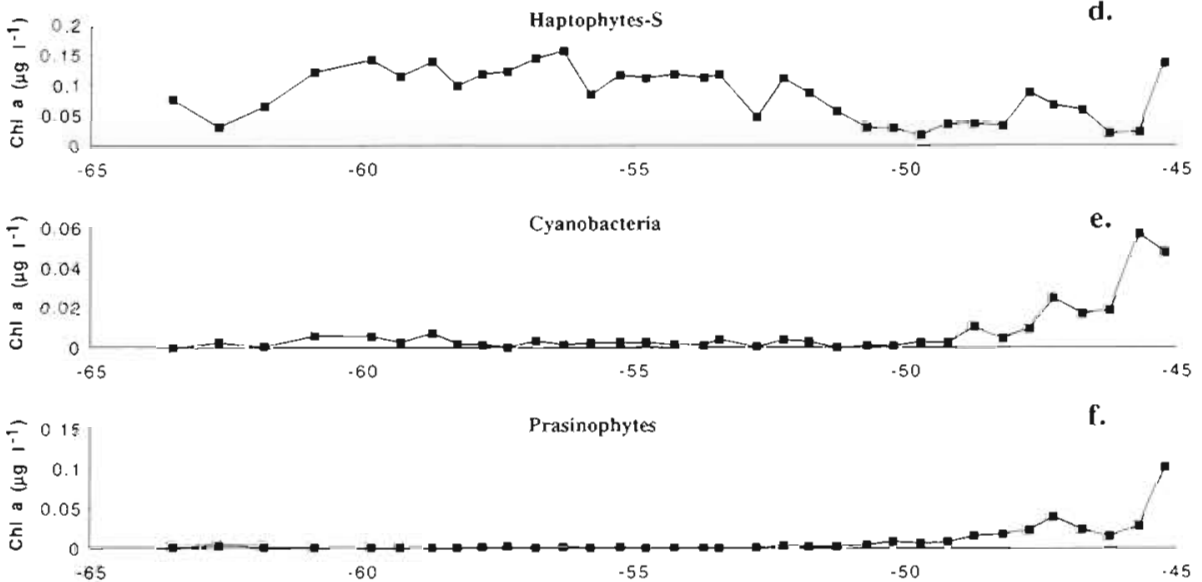

Fig. 8. Estimated contributions of various phytoplankton to the total concentrations of chl a as deter-

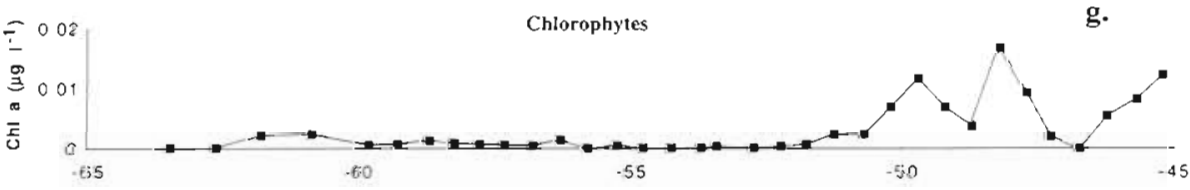
mined by interpretation of pigment HPLC data using the CHEMTAX program: (a) diatoms; (b) dinoflagellates; (c) haptophytes typical of northern latitudes (represented by Emiliania huxleyi); (d)

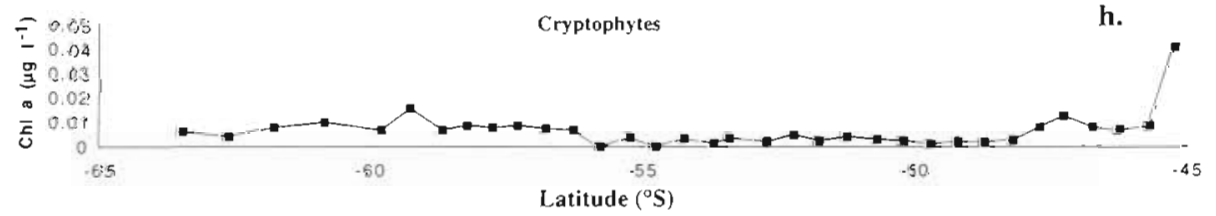
haptophytes typical of southern latitudes (represented by Phaeocystis antarctica); (e) cyanobacteria; (f) prasinophytes: (g) chlorophytes; (h) cryptophytes

Interpretation of complete data-set

The contributions of various classes to phytoplankton chl $a$, as interpreted by CHEMTAX on the complete data set, are shown in Fig. 8a-i. The interpreted abundance of diatoms (Fig. 8a) more closely followed the microscopic counts of small diatoms (Fig 5a) than large diatoms (Fig. 5b). CHEMTAX suggested that there were no diatoms north of $55^{\circ} \mathrm{S}$, although low numbers were observed by microscopy but generally the correspondence with the microscopic counts was good. This was surprising since the diatom species varied markedly along the transect (Fig. 6). Apparently, the pigment ratios of these species were not sufficiently different to cause problems with the computations.

Likewise, the interpreted abundance of dinoflagellates (Fig. 8b) correlated more closely with microscopic counts of small dinoflagellates (Fig. $5 \mathrm{c}$ ) than large (Fig. 5d). The interpreted abundance clearly followed that of peridinin and the small peak at $48^{\circ} \mathrm{S}$, which was associated with the flagellate peak, was apparent in the CHEMTAX output. It is likely that many of the dinoflagellates present were heterotrophic, especially the larger ones. These would have been counted microscopically but would not have contained peri- 
dinin or chl $a$, and hence would not have contributed to the CHEMTAX results.

The interpreted abundance of cyanobacteria is shown in Fig. 8e. The general trend follows that of the cyanobacterial fluorescence counts (Fig. 5f), except that CHEMTAX predicted that some cyanobacteria were present south of $50^{\circ} \mathrm{S}$ (following zeaxanthin concentrations) whereas none were observed. Apparently, zeaxanthin from chlorophytes or prasinophytes in this region was not fully ascribed to these sources and was interpreted as coming from cyanobacteria.

CHEMTAX interpretations of classes likely to be represented in the flagellates are shown in Fig. $8 \mathrm{c}, \mathrm{d}$, $\mathrm{f}-\mathrm{h}$. As with the dinoflagellates, the proportion of heterotrophic cells in the microscopic flagellate category is unknown, but it is likely to be of a magnitude similar to that of autotrophic cells. Heterotrophic flagellates would not influence the CHEMTAX results. Two categories of haptophytes are shown in Fig. 8c, d. These were originally based on our designation of northerly populations (Haptophytes $-N$, represented by Emiliania huxleyl) and southern populations (Haptophytes-S, represented by Phaeocystis antarctica). Although the calculations were not constrained by latitude, CHEMTAX found that the Haptophytes- $N$ category did not occur south of $53^{\circ} \mathrm{S}$, and that the Haptophytes-S category dominated there and was reduced north of $50^{\circ} \mathrm{S}$.

This result was very encouraging because the 2 categories had qualitatively identical pigment compositions, although in different proportions (Table 1). This similarity meant that extreme care had to be used in selecting the initial pigment ratios to distinguish the 2 populations of haptophytes and in controlling the degree to which the CHEMTAX program could alter these ratios (using a ratio limits file: see Mackey et al. 1996). When the ratio limits file allowed almost unrestricted changes in the pigment ratios $1500 \%$ variation), the final $19^{\prime}$-but pigment ratio of Haptophytes-S for this data-set was almost as large as the final fucoxanthin ratio and the plots of haptophyte-specific chl a were unrealistic.

Literature values (Wright \& Jeffrey 1987) and unpublished data (S. W. Wright \& A. T. Davidson) for Phaeocystis antarctica suggest that the $19^{\prime}$-but ratio is less than that for fucoxanthin. Consequently the initial 19'but ratio for Haptophytes-S was set substantially lower than the fucoxanthin ratio and the ratio limits were set to $100 \%$ allowing a maximum 2 -fold variation in the ratios. Although the CHEMTAX program was quite sensitive to changes in the initial 19'-but ratio for this data-set, the program was less sensitive to changes in other pigments. Changes of the order of 5 to $10 \%$ for the initial ratios had very little effect on the recovery of class-specific chl a across the transect.
The interpreted abundance of prasinophytes (Fig. 8f) was greater than that of chlorophytes (Fig. 8g). Both had peaks associated with the peak in flagellate numbers at $47^{\circ} \mathrm{S}$ (Fig. 5e), although the distribution of prasinophytes was displaced to the north of that of the chlorophytes. There are at least 3 types of pigment composition in oceanic prasinophytes (Mackey et al. 1996) with zeaxanthin:chl a ratios ranging from 0 to 0.283 . We have used ratios covering this range with our data-set and found the CHEMTAX results to be remarkably tolerant; the results for other ratios show little difference from that shown here with no prasinophyte zeaxanthin.

The interpreted abundance of cryptophytes (Fig. 8h) was low across the transect with small peaks at $59^{\circ}$ and $47^{\circ} \mathrm{S}$ and a large peak at the northernmost point. These data followed the distribution of alloxanthin, an unequivocal marker for Cryptophyceae. Cryptophytes have been observed previously in Antarctic coastal waters by Buck \& Garrison (1983), who found the cryptophyte Chroomonas sp. in the Weddell Sea in the area nearest the coast and Taylor \& Lee (1971), who found Cryptomonas criophila beneath the sea-ice in the Weddell Sea; however, no cryptophytes were encountered during our microscopical analysis. This situation parallels that of Gieskes \& Kraay (1983), who found sufficient alloxanthin in the North Sea to indicate large numbers of cryptophytes in the water column, but also observed none by microscopy. They concluded that cryptophytes were present but did not survive the fixation process. As discussed earlier, an alternative source of alloxanthin may be endosymbiotic cryptophytes in the ciliate Mesadinium rubrum. This source cannot be excluded on the basis of pigment composition.

\section{Interpretation of split data-set}

When the data set was split into two at the Polar Front, the results were less satisfactory. A sharp discontinuity was shown at the Polar Front that did not correspond to microscopical observations. This was contrary to expectations. We ascribe the superiority of the complete data-set over the split set to: (1) the relatively constant pigment ratio within the diatoms across the transect; (2) the inclusion of 2 haptophyte categories that accommodated the natural split of the haptophytes between the northern and southern populations; and (3) the minor proportion of cyanobacteria, chlorophytes and prasinophytes in the southern populations compared with the northern populations (pigment ratios could be optimized for these taxa in northern samples, but differences in these ratios in southern samples would have only a small effect on the total 
pigment composition). It would appear that these effects, plus the constraining effect of the greater sample numbers in the complete set, overrode the benefits of splitting the data into more homogenous subsets.

\section{CONCLUSIONS}

Each of the techniques used in this study gave a selective view of the phytoplankton populations across the transect. Microscopic data is certainly the least equivocal for robust classes (diatoms, dinoflagellates and cyanobacteria), but gave little information on others.

Pigment analysis complemented microscopic results well and implied the presence of haptophytes, cryptophytes (possibly endosymbiotic) and green algae where none were observed by microscopy. Multiple linear regression of pigment data (Gieskes et al. 1988) was not attempted in this study but would not have been able to distinguish fucoxanthin of diatoms from that of haptophytes, or among the many other phytoplankton groups that lack unequivocal markers.

CHEMTAX interpretation of pigment data allowed 2 populations of haptophytes to be distinguished even though they had qualitatively identical pigment compositions. It implied that the northern type of these two (represented by Emiliania huxleyi) was not found south of the Polar Front, a result consistent with previous microscopical studies (e.g. Nishida 1986). Similarly, Prasinophyceae and Chlorophyceae were distinguished and their separate distributions established.

CHEMTAX computed that small proportions of cyanobacteria were present in southern samples where none were observed by microscopy. This was probably due to slight errors in the calculation of zeaxanthin concentrations of chlorophytes and prasinophytes. Since computed abundance of cyanobacteria was not constrained by pigments other than zeaxanthin, any errors in these estimates would be reflected in the cyanobacterial computation. This is unlikely to be a problem in other oceans where cyanobacteria are a major component of the population

CHEMTAX was able to give reasonable results across a transect covering diverse areas where the species distributions varied widely. It would be expected that the program would give even better results if the survey was restricted to a smaller geographic area. For many of the algal classes, CHEMTAX did not change the initial pigment ratios so long as they were within about 10 to $20 \%$ of the initial 'guess' based on the SCOR workshop values. Using a synthetic data-set with the same number of algal classes, pigments and samples, and random normal errors of $25 \%$ added to the pigment ratio matrix, Mackey et al. (1996) found a residual error of 0.03 when a random normal error of $10 \%$ was added to the data-set. The real error in the analytical data for the pigment concentrations is expected to be much lower than $10 \%$. The residual error of the fit shown in Fig. 8 was significantly worse $(0.12)$. However, the program assumes that each taxonomic category has a consistent set of pigment ratios across all samples. This was not true in the present case where the samples were collected from waters ranging from the Antarctic coast to temperate regions. There would be changes expected across the transect both in the pigment ratios within a given algal species and in the species composition of an algal class. Indeed, the diatom species varied markedly along the transect. The program also assumes that all taxonomic groups present are included in the pigment ratio table. This was the case with the synthetic data but is unlikely to be true for the field data.

CHEMTAX analysis requires a table of expected taxonomic groups and their pigment ratios. It is necessary to have a reasonable idea of the species present to construct such a table, and thus some microscopic analysis is essential. Our application of the CHEMTAX program was limited by the lack of known pigment ratios for the study area. This would be the case in most studies; however, literature values derived from cultures proved to be adequate starting points for adjustment by the program. Obviously, it would be better if values for local populations were available.

This study provides an example of how CHEMTAX can enhance the complementarity of microscopy and pigment analysis. Only a combination of light- and electron-microscopy can determine the species composition of phytoplankton populations, but these techniques are too time-consuming for analysis of hundreds of samples in ecological studies. Pigment analysis does not have the taxonomic precision of microscopy but can accommodate the sample numbers required for spatial or temporal studies of phytoplankton distribution and interpolate between microscopic samples. The CHEMTAX program was able to distinguish taxa from the pigment data that would be otherwise unrecognisable.

In this study, only pigment data were interpreted by the program, but it would be capable of interpreting any set of taxon-associated markers (e.g. lipids) or combinations thereof.

\section{LITERATURE CITED}

Bjornland T, Liaaen-Jensen S (1989) Distribution patterns of carotenoids in relation to chromophyte phylogeny and systematics. In: Green JC, Leadbeater BSC, Diver WL (eds) The Chromophyte algae: problems and perspectıves. Clarendon Press, Oxford, p 37-61

Booth BC, Marchant HJ (1987) Parmales, a new order of 
marine Chrysophytes, with descriptions of three new genera and seven new species. J Phycol 23:245-260

Buck KR, Garrison DL (1983) Protists from the ice-edge region of the Weddell Sea. Deep Sea Res 30:1261-1277

Chisholm SW, Olson RJ, Zettler ER, Goericke R, Waterbury JB, Welschmeyer NA (1988) A novel free-living prochlorophyte abundant in the oceanic euphotic zone. Nature 334 : 340-343

Deacon GER (1982) Physical and biological zonation in the Southern Ocean. Deep Sea Res 29:1-15

Edwards RJ, Emery WJ (1982) Australasian Southern Ocean frontal structure during Summer 1976-77. Aust J Mar Freshwat Res 33: 3-22

El-Sayed SZ, Fryxell G (1993) Phytoplankton. In: Friedmann EI (ed) Antarctic microbiology. Wiley-Liss, New York, p $65-122$

Garmson DL, Gowing MM (1993) Protozooplankton. In: Friedmann EI (ed) Antarctic microbiology. Wiley-Liss, New York, p 123-165

Gieskes WWC, Kraay GW (1983) Dominance of Cryptophyceae during the phytoplankton spring bloom in the central North Sea detected by HPLC analysis of pigments. Mar Biol 75:179-185

Gieskes WWC, Kraay GW, Nontji A, Setiapermana D, Sutomo (1988) Monsoonal alteration of a mixed and a layered structure in the phytoplankton of the euphotic zone of the Banda Sea (Indonesia): a mathematical analysis of algal pigment fingerprints. Neth J Sea Res 22:123-137

Gordon AL, Georgi DT, Taylor HW (1977) Antarctic Polar Front Zone in the western Scotia Sea - summer 1975 J Phys Oceanogr 7:309-328

Harris GP, Ganf GG, Thomas DP (1987) Productivity, growth rates and cell size distributions of phytoplankton in the southwest Tasman Sea: implications for carbon metabolism in the photic zone. J Plankton Res 1987:1003-1030

Hasle GR (1969) An analysis of the phytoplankton of the Pacific Southern Ocean: abundance, composition and distribution during the Brategg Expedition 1947-48. Hvalrådets Skr 52:1-168

Hasle GR, Syvertsen EE (1996) Marine diatoms. In: Tomas CR (ed) Identifying marine diatoms and dinoflagellates. Academic Press, San Diego, p 5-385

Hewes CD, Holm-Hansen O, Sakshaug E (1985) Alternative carbon pathways at lower trophic levels in the Antarctic food web. In: Siegfried WR, Condy PR, Laws RM (eds) Antarctic nutrient cycles and food webs. Springer-Verlag, Berlin, p 277-283

Hibberd DJ (1977) Observations on the ultrastructure of the cryptomonad endosymbiont of the red-water ciliate Mesodinium rubrum. J Mar Biol Ass UK 57:45-61

Jeffrey SW (in press) Applications of pigment methods to oceanography. In: Jeffrey SW, Mantoura RFC, Wright SW (eds) Phytoplankton pigments in oceanography: a guide to advanced methods. SCOR-UNESCO, Paris

Jeffrey SW, Mantoura RFC, Wright SW (in press) Phytoplankton pigments in oceanography: a guide to advanced methods. SCOR-UNESCO, Paris

Jeffrey SW, Sielicki M. Haxo FT (1975) Chloroplast pigment patterns in dinoflagellates. J Phycol 11:374-384

Jeffrey SW, Vesk $M$ (in press) Introduction to marine phytoplankton and their pigment signatures. In: Jeffrey SW Mantoura RFC, Wright SW (eds) Phytoplankton pigments in oceanography: a guide to advanced methods. SCORUNESCO, Paris

Jeffrey SW, Wright SW (1994) Photosynthetic pigments in the Haptophyta. In: Green JC, Leadbeater BSC (eds) The haptophyte algae. Clarendon Press, Oxford, p 111-132
Kopczynska EE, Weber LH, El-Sayed SZ (1986) Phytoplankton species composition and abundance in the Indian sector of the Antarctic Ocean. Polar Biol 6:161-169

Li WKW, Wood AM (1988) Vertical distribution of North Atlantic ultraphytoplankton: analysis by flow cytometry and epifluorescence. Deep Sea Res 35:1615-1638

Lutjeharms JRE (1985) The South African SIBEX I cruise to the Prydz Bay region 1984: Ill. Jetall of the upper thermal structure of the Southern Ocean between South Africa and Prydz Bay during March-May 1984. S Afr T Nav Antarkt 15:12-18

Mackey MD, Mackey DJ, Higgins HW, Wright SW (1996) CHEMTAX - A program for estimating class abundances from chemical marker: application to HPLC measurements of phytoplankton pigments. Mar Ecol Prog Ser 144:265-283

Marchant HJ (1985) Choanoflagellates in the Antarctic marine food chain. In: Siegfried WR, Condy PR, Laws RM (eds) Antarctic nutrient cycles and food webs. SpringerVerlag, Berlin, p 271-276

Marchant HJ, Davidson A, Wright SW (1987) The distribution and abundance of chroococcoid cyanobacteria in the Southern Ocean. Proc NIPR Symp Polar Biol 1:1-9

Marchant HJ, McEldowney A (1986) Nanoplanktonic siliceous cysts from Antarctica are algae. Mar Biol 92:53-57

Marchant HJ, Murphy E (1994) Interactions at the base of the Antarctic food web. In: El-Sayed SZ (ed) Southern Ocean ecology; the BIOMASS perspective. Cambridge University Press, Cambridge, p 267-285

Millie DF, Paerl HW, Hurley JP (1993) Microalgal pigment assessments using high-performance liquid chromatography: a synopsis of organismal and ecological applications. Can J Fish Aquat Sci 50:2513-2527

Nakai T, Hasumoto $H$, Nemoto $T$ (1986) Oceanographic conditions of the Australian sector of the Southern Ocean in the summer of 1983-1984. Mem Natl Inst Polar Res Tokyo Spec Issue 40:467-478

Nishida S (1986) Nannoplankton flora in the Southern Ocean, with special reference to siliceous varieties. Mem Natl Inst Polar Res Tokyo Spec Issue 40:56-68

Perris SJ, Laybourne-Parry J, Marchant HJ (1995) Widespread occurrence of populations of the unique autotrophic ciliate Mesodinium rubrum (Ciliophora: Haptorida) in brackish and saline lakes of the Vestfold Hills (Eastern Antarctica). Polar Biol 15:423-428

Roy $S$ (1987) High performance liquid chromatographic analysis of chloropigments. J Chromatogr 391:19-34

Satoh H, Watanabe K (1991) A red water-bloom caused by the ciliate Mesodinium rubrum in the Austral summer in the fast ice area near Syowa station Antarctica with notes on their photosynthetic rate. J Tokyo Univ Fish 78:11-18

Stauber JL, Jeffrey SW (1988) Photosynthetic pigments in fifty-one species of marine diatoms. J Phycol 24:158-172

Stoecker DK, Buck KR, Putt M (1993) Changes in the sea-ice brine community during the spring-summer transition, McMurdo Sound, Antarctica. II. Phagotrophic protists. Mar Ecol Prog Ser 95:103-113

Taylor DL, Lee CC (1971) A new cryptomonad from Antarc tica: Cryptomonas cryophila sp. nov. Arch Mikrobiol 75 269-280

Vaulot D, Partensky F, Neveux J, Mantoura RFC, Llewellyn CA (1990) Winter presence of prochlorophytes in the surface waters of the northwestern Mediterranean Sea. Limnol Oceanogr 35:1156-1164

von Bröckel K (1981) The importance of nanoplankton within the pelagic Antarctic ecosystem. Kiel Meeresforsch 5 $61-67$ 
Watanabe MM, Suda S, Inouye I, Sawaguchi T, Chihara M (1990) Leptodinium viride gen et sp. nov. (Gymnodiniales, Dinophyta) a green dinoflagellate with a chlorophyll a and b-containing endosymbiont. J Phycol 26:741-751

Watanabe MM, Takeda Y' Sasa T, Inouye I, Suda S, Sawaguchi T. Chihara M (1987) A green dinoflagellate with chlorophylls $a$ and $b_{\text {; }}$ morphology, fine structure of the chloroplast and chlorophyll composition. J Phycol 23: 382-389

Wright SW. Jeffrey SW (1987) Fucoxanthin pigment markers of marine phytoplankton analysed by HPLC and HPTLC. Mar Ecol Prog Ser 38:259-266

Wright SW, Jeffrey SW (in press) High resolution system for chlorophylls and carotenoids of marine phytoplankton. In: Jeffrey SW, Mantoura RFC, Wright SW (eds) Phytoplank-

This article was submitted to the editor ton pigments in oceanography: a guide to advanced methods. SCOR-UNESCO, Paris

Wright SW, Jeffrey SW, Mantoura RFC, Llewellyn CA, Bjørnland T, Repeta D, Weischmeyer N (1991) Improved HPLC method for the analysis of chlorophylls and carotenoids from marine phytoplankton. Mar Ecol Prog Ser 77: $183-196$

Wright SW, Shearer JD (1984) Rapid extraction and high performance liquid chromatography of chlorophylls and carotenoids from marine phytoplankton. J Chromatogr 294:281-296

Wyrtki K, Bennet EB, Edward B, Rochford DJ (1971) Oceanographic Atlas of the International Indian Ocean Expedition. National Science Foundation, Washington

Manuscript first received: April 23, 1996

Revised version accepted: September 9,1996 